\title{
Effect of Age of Seedlings at Staggered Planting and Spacing on Growth and Yield of Transplant Aman Rice (Cv. Brri Dhan 46)
}

\author{
Tipu Sultan*, Rais Uddin Rashed, Shawkat Islam Shawan, Swapan K P and Abdur Rahman Sarkar \\ Department of Agronomy, Bangladesh Agricultural University, Bangladesh \\ Submission: August 08, 2018; Published: September 17, 2018 \\ *Corresponding author: Tipu Sultan, Department of Agronomy, Bangladesh Agricultural University, Bangladesh, \\ Email: tipubjri@gmail.com
}

Abstract

An experiment was conducted to observe the effect of seedling age at staggered planting and spacing on the growth and yield of transplant Aman rice cv. BRRI dhan 46 . Three seedling ages viz. 30,45 and 60 days and six spacings viz. $25 \mathrm{~cm} \times 5 \mathrm{~cm}, 25 \mathrm{~cm} \times 10 \mathrm{~cm}, 25 \mathrm{~cm} \times 15 \mathrm{~cm}, 25 \mathrm{~cm} \times 20 \mathrm{~cm}$ $25 \mathrm{~cm} \times 25 \mathrm{~cm}$ and $20 \mathrm{~cm} \times 20 \mathrm{~cm}$ respectively were included in the experiment using a randomized completely block design with three replications. Growth, yield and yield contributing characters of transplant Aman rice were influenced by seedling age, spacing and their interactions. Fortyfive-days old seedlings with $20 \mathrm{~cm} \times 20 \mathrm{~cm}$ spacing produced the tallest plant. At harvest, 45 -days old seedlings produced the tallest plant, highest number of non-effective tillers hill-1, highest number of total grains panicle-1, highest grain yield and highest biological yield. Whereas 60 -days old seedlings produced the lowest grain yield, straw yield and biological yield and harvest index. The spacing $25 \mathrm{~cm} \times 15 \mathrm{~cm}$ produced the highest grain yield, highest straw yield and highest biological yield. In the interaction between seedling age and spacing the highest grain yield was obtained when 30-day old seedlings were transplanted with $25 \mathrm{~cm} \times 20 \mathrm{~cm}$ spacing, which was statistically identical to 45 -days old seedlings at the same spacing. From the results, it may be concluded that 45 -days old seedlings transplanted with $25 \mathrm{~cm} \times 15 \mathrm{~cm}$ to $25 \mathrm{~cm} \times 20 \mathrm{~cm}$ spacing appeared as the promising practice to obtain maximum grain yield of transplant Aman rice cv. BRRI dhan 46 under staggered transplanting condition.

Keywords: Transplanting; Staggered Planting; Spacing; Harvest index

\section{Introduction}

Farmers in Bangladesh generally grow transplant Aman rice by using seedling sown at one time in the nursery bed. But transplanting sometimes late due to unavailable circumstances viz. stagnant water due to flood, delay in land preparation etc. and they have to use the seedling from the same source after recession of flood water, availability of suitable condition for land preparation. Thus, the seedling age increases due to delay in transplanting, though they were sown at the same time. This practice of transplanting seedling at different days having different ages is termed as staggered planting. The age of seedling is an important factor because it has tremendous influence on the growth and development, tiller production, grain formation and other yield contributing characters of rice [1].

For optimum yield, age of seedlings at transplanting of a suitable variety at a particular season may not be suitable for other varieties at another season. The use of over aged seedling ultimately affects the general performance of crop and the yield of the crop reduces drastically. So, it is very important to find out the optimum age of seedlings of a variety for a particular season. Spacing is another important factor that influences the growth, development, yield and yield components of transplanted rice. Optimum plant spacing ensures the plant to grow properly with their aerial and underground parts utilizing more solar radiation and nutrients [2]. When the plant spacing exceeds an optimum level, competition among plants for light becomes severe. Consequently, the plant growth slows down and ultimately the grain yield decreases. The tillering habit and production of spikelets panicle- 1 depends to a great extent on the spacing of transplanting which is responsible for the variation of yield in rice.

BRRI dhan 46 is a released transplant Aman rice variety. More clarification is needed in case of its agronomic practices and so more investigations are needed to determine the optimum age of seedling and plant spacing for this cultivar. Therefore, an experiment was conducted with the following objectives:

a. To find out the optimum seedling age at staggered planting of the transplant Aman rice cv. BRRI dhan 46;

b. To identify the suitable spacing at staggered planting of the transplant Aman rice cv. BRRI dhan 46 and

c. To observe the interaction effect (if any) between seedling age and plant spacing on the growth, yield and yield components of transplant Aman rice cv. BRRI dhan 46 . 


\section{Materials and Methods}

The experiment was carried out at the Agronomy Field Laboratory of Bangladesh Agricultural University (BAU) form June 2015 to November 2015 to evaluate the combined effect of seedling age at staggered planting and spacing on the growth and yield of transplant Aman rice cv. BRRI dhan 46 .

\section{Plant material used}

BRRI dhan 46, a high yielding cultivar of transplant Aman rice, was used as the test crop in the experiment. This variety was developed by the Bangladesh Rice Research Institute (BRRI) in 2007 as transplant Aman rice.

\section{Transplanting seedlings}

Thirty-day old seedlings were transplanted on 10 August 2015 at the rate of 3 seedlings hill-1 with six spacing as per treatment. Forty-five-day old seedlings were transplanted on 25 August 2015 with similar seedling rate and spacing. Then sixtyday old seedlings were transplanted on 14 September 2015 with similar seedling rate and spacing.

\section{Sampling, harvesting and processing}

Harvesting was done depending upon the full maturity of crop. Maturity of crop was determined when $90 \%$ of the grain became golden yellow color. Five hills from each plot excluding border hills were selected at random prior to harvesting and to record the data on yield attributes. These plants were taken out with respective tag levels. An area of central $5 \mathrm{~m} 2$ in each plot excluding the crop sampling zone was harvested for measurement of grain and straw yields on 30 November 2015. The harvested crop of each plot was separately bundled, properly tagged and then brought to the threshing floor. Finally, grain and straw yields were adjusted to $14 \%$ moisture and converted to t ha- 1 .

\section{Data collection}

\section{Data collection during growth stages}

Data were recorded for measuring growth parameters For this reason, five hills (excluding broader hills) from each plot were selected randomly and tagged for measuring the following characters at 15-day interval beginning 20 days after transplanting (DAT) upto 65 DAT
a. Plant height
b. Number of total tillers hill-1
c. Leaf area Index (LAI)
d. Total dry matter hill-1

\section{Procedure of data collection during growth stages}

Plant height and Number of tillers hill-1 Five plants plot-1 were selected randomly and plant height was measured, and Number of tillers was counted at 20,35 and 50 DAT and 65 DAT, respectively.

\section{Leaf area index}

The leaves were collected from destructive samples two hills in each plot and kept in polythene bag then leaf area was measured by using leaf area meter in the central laboratory, BAU. Leaf area was recorded at-15-day intervals beginning from 25 DAT up to 55 DAT. Finally leaf area index was calculated with the following formula (Radford, 1967; Hunt 1978)

Leaf area index (LAI): Ratio of leaf area to its ground area

$$
\mathrm{LAI}=\frac{\mathrm{LA}}{\mathrm{P}}
$$

Where, LA = Leaf area

$\mathrm{P}=$ Ground area.

\section{Grain Yield}

Grains obtained from five square meter central area of each plot were sun dried and weighed carefully. The grains were weighed and converted to tha-1. Final grain yield was adjusted at $14 \%$ moisture content by using the following formula:

$$
\text { Moisture }=\frac{\text { Fresh weight }- \text { Oven dry weight }}{\text { Fresh weight } 100 \mathrm{Mc}} \times 10
$$

So, adjusted yield at $14 \%$ moisture content $=86 \times \mathrm{W}(100-14$ $=86$ )

Here, Mc= Moisture content of grain

$\mathrm{W}=$ Fresh weight of grain.

\section{Biological yield}

Grain yield and straw yield were altogether regarded as biological yield. The biological yield was calculated with the following formula:

Biological yield $=$ Grain yield + Straw yield.

\section{Harvest index}

Harvest index is the ratio of economic yield to biological yield and expressed as percentage (\%). Harvest index was calculated on the basis of adjusted grain and straw weight using the following formula.

Harvest index $(\%)=\frac{\text { Grain yield }}{\text { Grain yield }+ \text { Straw yield }} \times 100$

\section{Statistical analysis}

Data recorded for different parameters were compiled and tabulated in proper form for statistical analysis. The recorded data on various plant characters were statistically analyzed using "Analysis of variance technique" with the help of computer Package program MSTAT and the significance of mean difference was adjudged by Duncan's Multiple Range Test [3].

\section{Results and Discussion}

The Analysis of Variance (ANOVA) showed significant results in different parameters. 


\section{Growth parameters}

\section{Plant height}

\section{A. Effect of seedling age at staggered planting}

Plant height was significantly influenced by seedling age and 20 DAT, the highest plant height $(52.96 \mathrm{~cm})$ was obtained from 60-day old seedlings which was statistically identical to 45-day old seedlings and the lowest plant height $(31.54 \mathrm{~cm})$ was obtained from 30-day old seedling. At 35 DAT, the highest plant height $(79.63 \mathrm{~cm})$ was recorded from 45 -day old seedlings which was statistically identical to 30 - day old seedling and the lowest plant height $(62.98 \mathrm{~cm})$ was obtained from 30 - day old seedlings. At 50 DAT, the highest plant height $(93.84 \mathrm{~cm})$ was obtained from 30 day old seedlings which was statistically identical to 45-day old seedlings and the lowest plant height $(78.78 \mathrm{~cm})$ was obtained from 60-day old seedling. At 65 DAT, the highest plant height $(105.65 \mathrm{~cm})$ was obtained from 45 -day old seedlings which was statistically identical to 30-day old seedlings and the lowest plant height $(95.18 \mathrm{~cm})$ was obtained from 60 -day old seedlings (Figure 1).

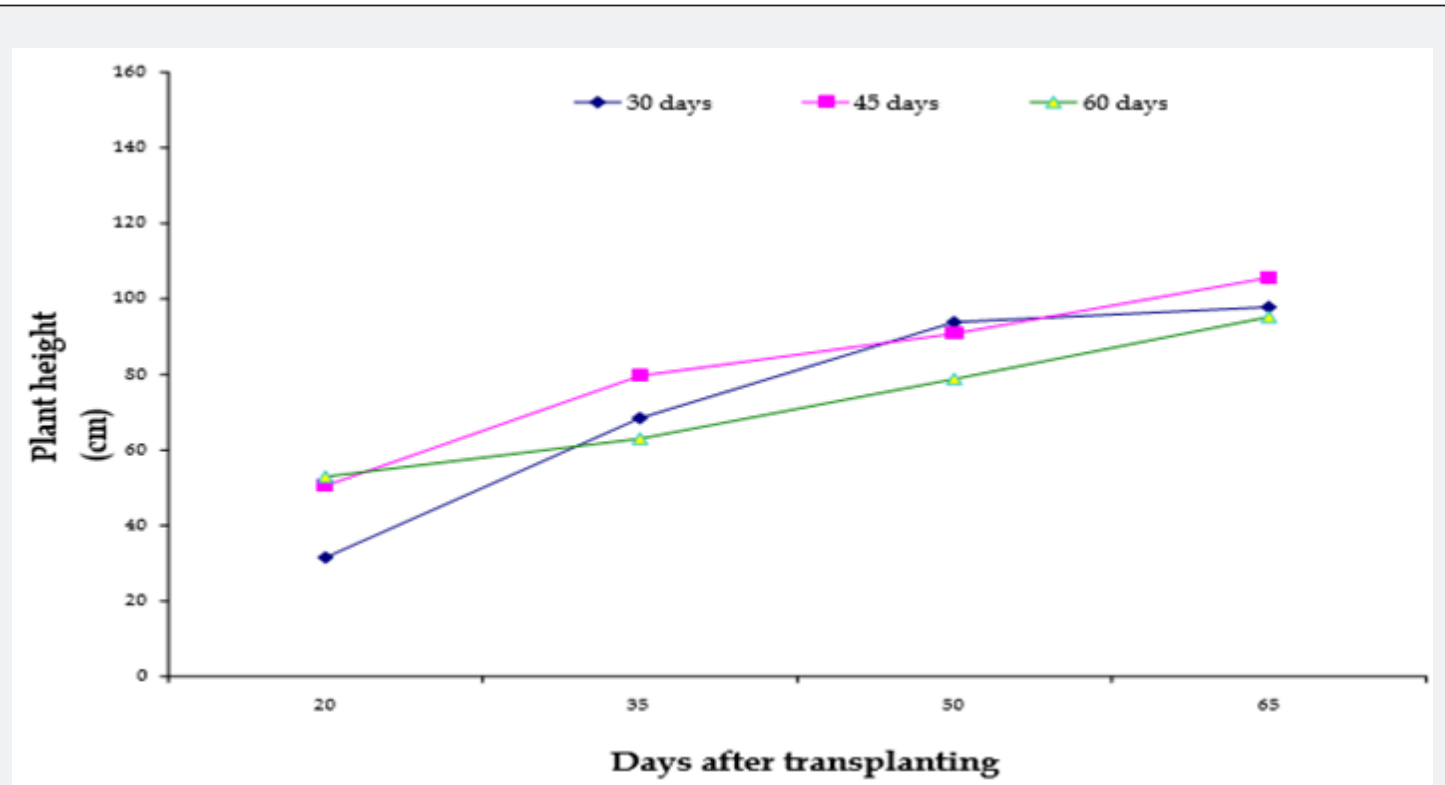

Figure 1: Effect of age of seedlings at staggered planting on plant height at different days after transplanting of transplant Aman rice (cv. BRRI dhan46).

\section{B. Effect of spacing} affected due to the spacing (Figure 2).

The results showed that the plant height was not significantly

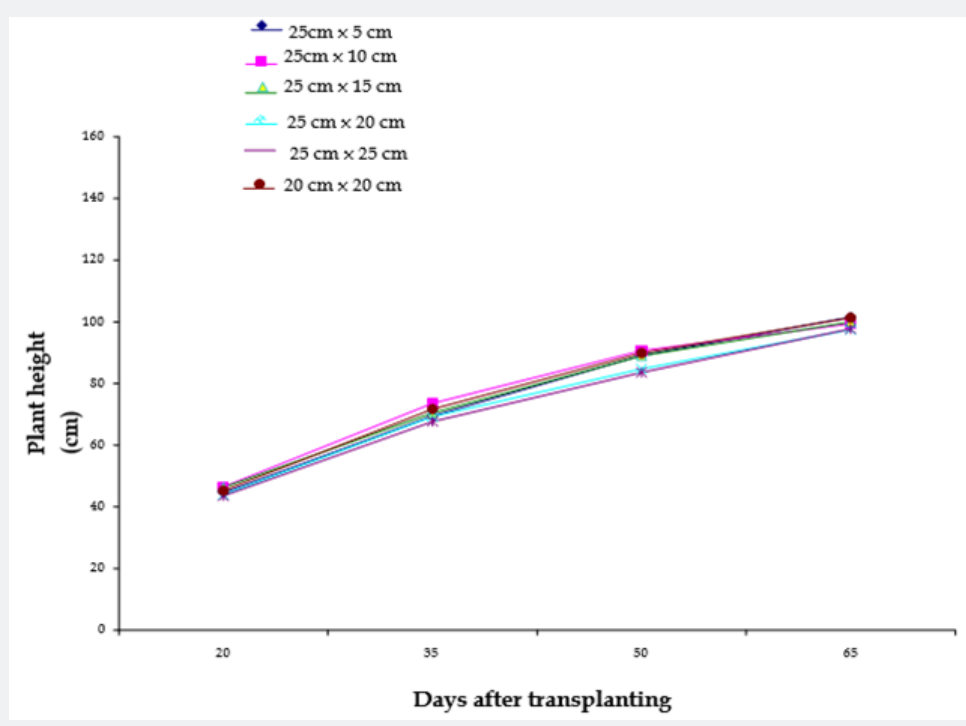

Figure 2: Effect of spacing on plant height at different days after transplanting of transplant Aman rice (cv. BRRI dhan46). 


\section{Effect of interaction between seedling age and} spacing

Plant height was significantly influenced due to the interaction between seeding age at staggered planting and spacing at 65 DAT. At 65 DAT, the highest plant height $(111.33 \mathrm{~cm})$ was obtained at $20 \mathrm{~cm} \times 20 \mathrm{~cm}$ spacing with 45 -day old seedling which was statistically identical to $25 \mathrm{~cm} \times 10 \mathrm{~cm}, 25 \mathrm{~cm} \times 15 \mathrm{~cm}$, $25 \mathrm{~cm} \times 20 \mathrm{~cm}$ spacing with 45 -day old seedling.

\section{Number of panicles hill-1}

\section{A. Effect of seedling age at staggered planting}

Number of panicles hill-1 was significantly influenced due to age of seedling. The highest number of panicles hill-1 (8.17) was obtained from 30-day old seedling which was statistically identical to 45-day old seedling. The lowest number of panicle hill-1 (7.2) was obtained from 60-day old seedling.

\section{B. Effect of spacing}

The results showed that number of panicles hill-1 was not significantly affected due to spacing.

C. Effect of interaction between seedling age and spacing

The results showed that number of panicles hill-1 was not significantly affected due to interaction between seedling age and spacing.

\section{Number of grains panicle-1}

\section{A. Effect of seedling age at staggered planting}

The effect of seedling age on grains panicle-1 was found to be significant. The highest number of grains panicle-1 (92.19) was obtained from 30-day old seedlings, which was statistically identical to 45- day old seedling. The lowest number of grains panicle-1 (80.86) was obtained from 60-day old seedlings.

\section{B. Effect of spacing}

The results showed that spacing had significant effect on the production of grains panicle- 1 . Wider spacing of $25 \mathrm{~cm} \times 25 \mathrm{~cm}$ produced the highest number of grains panicle-1 (95.65) which differed from other treatments. The lowest number of grains panicle-1 (85.23) was obtained from closer spacing of $25 \mathrm{~cm}$ $\times 5 \mathrm{~cm}$. From the results it was observed that wider spacing produced more number of grains panicle- 1 than closer ones.

\section{Effect of interaction between seedling age and} spacing

Number of grains panicle-1 was significantly influenced due to seedling age and spacing. The highest number of grains panicle-1 (106.41) was obtained from $25 \mathrm{~cm} \times 25 \mathrm{~cm}$ spacing and 45-day old seedlings. The lowest number of grains panicle-1 (70.74) was obtained from 60 -day old seedling with $25 \mathrm{~cm} \times$ $10 \mathrm{~cm}$ spacing.

\section{Weight of 1000 grains}

\section{A. Effect of seedling age}

The weight of 1000 grains were significantly influenced due to age of seedling. The highest weight of 1000 grains (25.38g) was obtained from 30-day old seedlings, which was statistically identical to 45-day old seedlings. The lowest weight of 1000 grains (22.48g) was obtained from 60-day old seedlings.

\section{B. Effect of spacing}

The weight of 1000 grains had no significant effect due to spacing (Appendix IV). This result is in agreement with the findings of Hwua and Theseng (1982) who stated that spacing had no significant effect on 1000-grain weight.

\section{Effect of interaction between seedling age and} spacing

The interaction between seedling age and spacing exerted no significant effect on 1000-grain weight.

\section{Grain yield}

Grain yield was significantly influenced by seedling age. The highest grain yield (4.51 t ha-1) was obtained from 45-day old seedlings. The lowest grain yield (3.98 tha-1) was obtained from 60-day old seedlings which was statistically identical with 30 day old seedlings.

\section{Effect of spacing}

Spicing had significant effect on grain yield. The highest grain yield (4.76 t ha-1) was obtained from wider spacing of $25 \mathrm{~cm}$ $\times 15 \mathrm{~cm}$. The lowest grain yield $(4.01 \mathrm{t}$ ha-1) was obtained from closer spacing of $25 \mathrm{~cm} \times 5 \mathrm{~cm}$. The results showed that grain yield increased with increasing spacing.

B. Effect of interaction between seedling age and spacing

Grain yield was significantly influenced by the interaction between seedling age and spacing. The highest grain yield $(4.84 \mathrm{t}$ ha-1) was obtained from 30-day old seedlings with $25 \mathrm{~cm} \times 15 \mathrm{~cm}$ spacing. The lowest grain yield ( $3.67 \mathrm{t}$ ha-1) was obtained from 30 -day old seedlings with $20 \mathrm{~cm} \times 20 \mathrm{~cm}$ spacing.

\section{Biological yield}

\section{A. Effect of seedling age at staggered plantings}

Biological yield was significantly influenced by seedling age. The highest biological yield (11.62 t ha-1) was obtained from 45-day old seedlings. The lowest biological yield (10.21 t ha-1) was obtained by transplanting 30-day old seedlings, which was statistically identical to 60-day old seedling.

\section{B. Effect of spacing}

Spacing had significant effect on biological yield. The highest biological yield (11.57 t ha-1) was obtained from wider spacing $(25 \mathrm{~cm} \times 15 \mathrm{~cm})$. The lowest biological yield $(10.20 \mathrm{t}$ ha-1) was obtained from closer spacing $(25 \mathrm{~cm} \times 10 \mathrm{~cm})$ the result showed that wider spacing produced more biological yield than wider spacing. 
C. Effect of interaction between seedling age and spacing of transplanting

The interaction effect of seedling age and spacing was significant on biological yield. The highest biological yield $(13.43$ t ha-1) was obtained from 45-day old seedlings with $20 \mathrm{~cm} \times$ $20 \mathrm{~cm}$ spacing. The lowest biological yield $(8.23 \mathrm{t}$ ha- 1$)$ was obtained from 30 -day old seedlings with $20 \mathrm{~cm} \times 20 \mathrm{~cm}$ spacing.

\section{Harvest index}

\section{A. Effect of seedling age at staggered planting}

Harvest index was significantly influenced due to seeding age. The highest harvest index $(40.66 \%)$ was obtained by transplanting 30-day old seedlings. The lowest harvest index $(37.92 \%)$ was obtained from 60-day old seedling which, was statistically identical to 45 -day old seedling.

\section{B. Effect of spacing}

The results showed that harvest index was not significantly affected due to spacing.

\section{Effect of interaction between seedling age and spacing}

The interaction effect between seedling age and spacing was significant on harvest index. The highest harvest index (42.28\%) was obtained from 30-day old seedlings with $25 \mathrm{~cm} \times 10 \mathrm{~cm}$ spacing. The lowest harvest index (35.56\%) was obtained from 60 -day old seedlings with $25 \mathrm{~cm} \times 5 \mathrm{~cm}$ spacing.

\section{Conclusion}

Its observed that, forty-five days old seedlings and $20 \mathrm{~cm} \times$ $20 \mathrm{~cm}$ spacing produced the tallest plant at 65 DAT. Forty-five-day old seedlings produced the tallest plant, highest number of total spikelets panicle-1, highest grain yield and highest biological yield. Whereas 60 -day old seedlings produced the lowest grain yield, straw yield and biological yield and the lowest harvest index.

All parameters studied atharvest were significantly influenced due to spacing except length of panicle, number of panicles hill1,1000 -grain weight and harvest index. Wider spacing of $25 \mathrm{~cm}$ $\times 25 \mathrm{~cm}$ produced the highest plant height, highest number of effective tillers hill-1, highest number of non-effective tillers hill1 and highest number of grains panicle-1, which were similar to $25 \mathrm{~cm} \times 15 \mathrm{~cm}$ spacing. Spacing of $25 \mathrm{~cm} \times 15 \mathrm{~cm}$ produced the highest grain yield, highest straw yield, highest biological yield. Whereas the closer spacing of $15 \mathrm{~cm} \times 5 \mathrm{~cm}$ produced the shortest plant, lowest number of tillers hill-1, lowest number of effective tillers hill-1, highest non-effective tillers hill-1 and lowest grain yield, straw yield and biological yield. The interaction of seedling age and spacing had significant effect on most of the parameters except plant height and 1000 grain weight. In the interaction between seedling age and spacing the highest grain yield was obtained when 30-day old seedlings were transplanted with $25 \mathrm{~cm} \times 20 \mathrm{~cm}$ spacing, which was statistically identical to 45 day old seedlings at the same spacing. The lowest grain yield, straw yield and biological yield were obtained from 30-day old seedlings with $20 \mathrm{~cm} \times 20 \mathrm{~cm}$ spacing.

From the results of the present experiment it may be concluded that 45 -days old seedlings transplanted with $25 \mathrm{~cm} \times$ $15 \mathrm{~cm}$ to $25 \mathrm{~cm} \times 20 \mathrm{~cm}$ spacing appeared as the promising practice to obtain maximum grain yield of transplant Aman rice cv. BRRI dhan46 under staggered transplanting condition [4-6].

\section{References}

1. Islam MA, Ahmed JU (1981) Effect of age of seedlings on the yield of transplant aman rice cultivars. Bangladesh J Agril Sci 8(2): 175-179.

2. Miah MHN, Karim MA, Rahman MS, Islam MS (1990) Performance of Nizersail mutants under different row spacing. Bangladesh J Train Dev 3(2): 31-34.

3. Gomez KA, Gomez AA (1984) Statistical Procedures for Agricultural Research. ( $2^{\text {nd }}$ ed). John Wiley and Sons. New York p. 68.

4. BRRI (Bangladesh Rice Research Institute.) (1991) Annual Report for 1988. Bangladesh Rice Res. Inst., Joydebpur, Gazipur, Bangladesh: 1023.

5. Islam, M Shohidul Islam, Shafiqul Rahman, Md Akhter, Mst A K Azad (2008) Performance of aromatic rice varieties as influenced by spacing. J Innov Dev Strategy 2: 43-46.

6. Rekhashri K, Borthakur MP, Sarmah BN, Kalita R (1997) Effect of planting geometry and levels of fertilizer on yield parameters, yield and uptake of late planted sali rice. J Agril Sci Soc North East India 10(2): 256-258.

\section{Your next submission with Juniper Publishers} will reach you the below assets

- Quality Editorial service

- Swift Peer Review

- Reprints availability

- E-prints Service

- Manuscript Podcast for convenient understanding

- Global attainment for your research

- Manuscript accessibility in different formats

( Pdf, E-pub, Full Text, Audio)

- Unceasing customer service

Track the below URL for one-step submission https://juniperpublishers.com/online-submission.php 